\title{
无序的新境界：高熵陶瓷
}

\author{
张国军 ${ }^{1}$, 王玉金 ${ }^{2}$
}

(1. 东华大学 功能材料研究中心, 上海 201620; 2. 哈尔滨工业大学 特种陶瓷研究所, 哈尔滨 150001)

人类社会的进步与发展对材料性能提出了越来越高的要求, 这是激励人们探索新的材料设计理论并开发新材 料体系的原动力。近年来, 性能优异的新材料不断涌现, 并相继成为研究热点, 由高熵合金发展而来的高熵陶瓷就 是典型代表之一。2004 年, 中国台湾清华大学叶均蔚和英国牛津大学 Cantor 两个课题组几乎同时提出了高摘合金 (High-entropy alloys)的概念。他们发现将(近)等原子比的多种合金元素高温熔炼, 容易形成金属原子随机分布的面 心立方、体心立方和六角密堆等具有简单晶体结构的单相固溶体，阻止了金属间化合物的生成，显示出典型的高熵 效应。此后人们进一步归纳出高熵合金的四大效应, 即热力学上的高熵效应、晶体学上的晶格畸变效应、动力学上 的迟滞扩散效应和性能上的 “鸡尾酒”效应。与传统合金相比, 高熵合金表现出良好的结构稳定性、优异的力学性能 以及功能特性, 引发了材料界研究高熵材料的热潮。

2015 年, 美国北卡罗莱纳州立大学的 Maria 和杜克大学的 Curtarolo 等首次报道了一种岩盐结构的 (MgNiCoCuZn)O 陶瓷, 可以将单斜晶系的 $\mathrm{CuO}$ 和六方晶系的 $\mathrm{ZnO}$ 固溶于面心立方晶体结构中, 这与传统陶瓷固溶 体形成准则(Hume-Rothery rules)相违背。该研究证明陶瓷材料中同样存在高熵效应, 从而将 “高熵”概念成功地由合 金引入陶瓷, 揭开了高熵陶瓷研究的序幕。不到 6 年时间, 高熵陶瓷发表论文多达 400 余篇。目前, 高熵陶瓷家族 不断壮大, 由各种晶体结构的氧化物陶瓷发展到嗍化物、碳化物、氮化物、硅化物、硫化物等非氧化物陶瓷体系, 甚 至扩展到多阴离子陶瓷体系和复相高熵陶瓷体系，潜在应用范围覆盖整个工业领域。

作为陶瓷界的新星, 高熵陶瓷成分复杂且研究体系庞大, 这给材料设计和制备带来了巨大的挑战。与此同时, 它还具有组分调节空间巨大、熵效应独特以及材料性能可调控等优点，是材料领域中一个尚待开采的富矿。目前， 高熵陶瓷的研究尚处于起步阶段, 大量工作聚焦于成分设计、单相形成能力、制备方法、基本性能等方面, 还存在 诸多问题亟待解决，如高熵合金的四个核心效应在高摘陶瓷中的普适性尚待验证，更精准的成分设计理论和单相 形成能力的统一判据有待建立，高熵陶瓷的组分-微结构-性能之间的关系需要挖掘等。

2020年春, 受《无机材料学报》编辑部的邀请, 我们开始组织编撰 “高熵陶瓷”专辑。在组稿过程中, 我们欣喜 地发现越来越多的研究者投身其中, 研究内容覆盖高熵陶瓷的各个方向。相信随着材料设计理论水平的提高, 高通 量计算和机器学习等先进手段的应用, 以及先进材料制备和表征技术的发展, 人们终将揭开高熵陶瓷的神秘面纱, 研究出各种力、热、声、光、电性能以及综合性能优异的高熵陶瓷并付诸实际工程应用。我们期待这一天早日到来!

\section{Non-order is the New Order: High-entropy Ceramics}

\section{ZHANG Guojun ${ }^{1}$, WANG Yujin ${ }^{2}$}

(1. Institute of Functional Materials, Donghua University, Shanghai 201620, China; 2. Institute for Advanced Ceramics, Harbin Institute of Technology, Harbin 150001, China)

The development of human society poses increasingly stringent requirements for material performances, motivating ever deeper exploration of novel design theories and material systems. Nowadays, state-of-the-art materials with excellent performances constantly emerge as research hotspots, of which high-entropy ceramics, originated from high-entropy alloys, are one typical representative. The concept of high-entropy alloys was proposed in 2004 by two independent research groups, Jien-Wei Yeh’s group at Taiwan Tsing Hua University, China, and Brian Cantor's group at Oxford University, UK. They found that seemingly disorderly groups of 
alloying elements with (near) equal atomic ratios can solidify into single-phase solid solutions with a simple crystal structure such as face-centered cubic, body-centered cubic, or hexagonal close-packed structure, and thus prevented the formation of intermetallic compounds, which demonstrated typical high-entropy effects. In the following years, the four core effects of high-entropy alloys were further proposed, namely the high-entropy effect in thermodynamics, the lattice distortion effect in crystallography, the sluggish diffusion effect in kinetics, and the “cocktail” effect in material performance. With enhanced structural stability, improved mechanical and functional properties, this rising star in the world of material science has evoked an upsurge of high-entropy material research.

In 2015, Jon-Paul Maria at North Carolina State University and Stefano Curtarolo at Duke University first reported a rock-salt type (MgNiCoCuZn)O entropy-stabilized oxide ceramics. The observed dissolution of both monoclinic $\mathrm{CuO}$ and hexagonal $\mathrm{ZnO}$ in a face-centered cubic crystal structure contradicted the traditional Hume-Rothery rule for solid solution formation. This proved the existence of high entropy effect in ceramic materials as well as alloys, thereby introducing the concept of "high entropy" into the field of advanced ceramics and marking the beginning of the research into high-entropy ceramics. In less than 6 years, as many as 400 papers on high-entropy ceramics have been published. At present, the family of high-entropy ceramics involves a wide variety of members, from oxide ceramics with various crystal structures to non-oxide ceramic systems such as borides, carbides, nitrides, silicides, sulfides, and to multi-anion systems and high-entropy ceramic multiphase systems, which is still continuously branching out. Its extraordinary application potentials have gained ground in numerous industries around the globe.

Granted, the complex chemical compositions of high-entropy ceramics and the intricacies of its knowledge system have brought about unprecedented challenges concerning material design and processing. On the other hand, they also present us the advantage of adjusting compositions with enormous latitude, utilizing the unique entropy effect, as well as finely tuning material properties. In light of those capabilities, high-entropy ceramics are considered as a rich academic ore worthy of mining. At present, it is still a relatively young research area, mainly focused on composition design, single-phase formation ability, processing methods, and basic performance evaluations, while many problems remain to be solved. For example, it is still not verified if the four core effects of high-entropy alloys are universally applicable in high-entropy ceramics, and more accurate component design theory as well as sound criteria for single-phase formation ability is also highly called for. Besides, the relationship between composition, microstructure and performance of high-entropy ceramics requires yet further investigation.

In the spring of 2020, at the invitation of the editors of the Journal of Inorganic Materials, we began to organize this special issue on high-entropy ceramics. During this process, we are pleased to find that more and more researchers in China are involved in this area covering all aspects of high-entropy ceramics. We believe that, with further improvement of material design theory, the application of high-throughput computing and machine learning as well as advanced characterization methods, the mystery of high-entropy ceramics will be gradually unveiled, and more high-entropy ceramics with outstanding mechanical, thermal, acoustic, optical, and electrical properties will be developed and eventually applied in industry. We look forward to witnessing these soon!

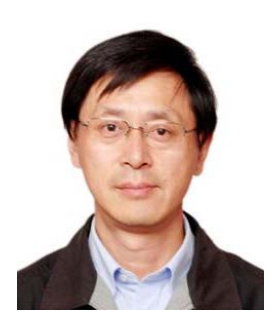

张国军, 博士, 东华大学教授。 中科院百人计划、上海市浦江人才 计划获得者。长期从事嗍化物、氮 化物、碳化物等非氧化物陶瓷的制 备科学、微结构调控与性能表征研 究。E-mail: gjzhang@dhu.edu.cn

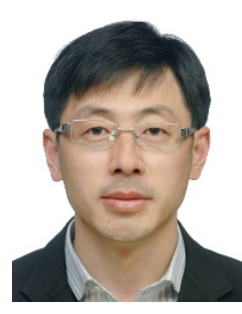

王玉金, 博士, 哈尔滨工业大 学教授。教育部新世纪人才。主要 从事超高温陶瓷、难熔金属基复合 材料的低温制备、组织性能调控及 应用等方面的教学和科研工作。 E-mail: wangyuj@hit.edu.cn 